\title{
Students' Internship and the Higher Education in Tourism in Support of the Regional Businesses: Methodology
}

\author{
Mariya Veleva, $\mathrm{PhD}$ \\ University of Economics - Varna, Varna, Bulgaria \\ maria.veleva@ue-varna.bg \\ Krasimira Yancheva, PhD \\ University of Economics - Varna, Varna, Bulgaria \\ krasimira_yancheva@ue-varna.bg
}

\begin{abstract}
The goal of this paper is to highlight the problems and opportunities for integrating university graduates in the tourism industry through their practical internship, and to propose a methodology for measuring its effectiveness. The research brings out the most common problems and peculiarities, in twelve countries, in the practical training of tourism students: overtime without payment; lack of supervision and control of the students' performance; insufficient on-boarding; lack of on-the-job training; students become subject to dark leadership and are directly discriminated against or denied full rights to work and fair pay; gap between too high job expectations and reality; The curricula does not always meet the needs of the tourism practice. Based on the analysis of the students' internship in the specialty "Tourism" at the University of Economics - Varna, a new methodology for measuring its effectiveness is proposed.
\end{abstract} methodology

Keywords: tourism, students' internship, higher education in tourism, tourism graduates, research

JEL Code: Z3; doi:10.36997/IJUSV-ESS/2019.8.1.129

\section{Въведение}

Туризмът е изключително трудоемък отрасъл, но също така е и важен източник на заетост. Според Международната организация на труда (ILO, 2019), той е сред най-добрите създатели на работни места в света, изискващи различни степени на умения и позволява бързо влизане в работната сила за младежи, жени и мигранти и представлява 30 на сто от експортните услуги в света. По отношение на веригата за доставки в сектора, едно работно място в основните индустрии на туризма - хотелиерството и храненето, косвено генерира приблизително 1,5 допълнителни работни места в съответната свързана икономика. През 2010 г. глобалната икономика на сектора е предоставила повече от 235 милиона работни места, което се равнява на около 8 на сто от общия брой работни места (директни и косвени), или едно на всеки 12,3 работни места. За 2019 г., Световната туристическа организация, с функции на агенция към ООН, предвижда туризмът в глобален аспект да осигури около 60 млн повече работни места - т.е. в цял свят, в туристическата индустрия ще работят 296 милиона работници (ILO, 2010).

Поради голямото предлагане на разнообразни по вид и качество туристически услуги, потребителите формират трайни очаквания по време на покупката си да бъдат обслужени от висококвалифицирани и мотивирани служители. Това е и основна причина, поради която се очаква провеждането на непрекъснато обучение и развитие на уменията на служителите, работещи във всички области на туризма да се превърне в неотменна част от управлението на хората в туристическите организации. Необходимите умения за работа в туризма почти винаги представляват сложен комплекс от различни комбинации (напр.: чуждоезикови познания и умения за комуникация, ориентираност към клиента, емоционална интелигентност и разрешаване на конфликти, информационни и комуникационни технологии и др.). Развитието на способностите на работниците чрез качествено образование, обучение, специализирана квалификация в няколко области и въздействието на ученето през целия живот, са също толкова важни за подпомагането на работниците да 
намерят добра работа, колкото и организациите да намерят компетентни професионалисти, отговорящи на потребителските изисквания. Европейският съюз, поради нарастващите изисквания към квалификацията на служителите от всички индустрии в ЕС, създава т.нар. Европаспорт. В тази връзка, проектът за паспорт на квалификацията и уменията (QSP) има за цел изграждането на единна платформа за подкрепа на миграцията на работната сила вътре в Европейската общност в сектора на хотелиерството с мобилизиране на актуални ИТ решения и в силна координация с вече съществуващите усилия на страните от ЕС (главно мрежата EURES и системата Europass). Проектьт QSP цели да подпомогне по-добрия поток на информация между работодатели и служители, подпомага процеса на вземане на решения на работодателите, събира и разпространява актуална и надеждна информация за пазара на труда, касаеща добре дефинирани различни умения, опит и компетенции на служителите, създаваопределената глобална, унифицирана база данни за работни места с добре организирано, търсено и проверено съдържание. В резултат на това се подпомагат решаването на проблеми, произтичащи от различното местоположение и езиковите различия, както и се засилва координацията на системите за образование и специално обучение на държави и региони в ЕС.

От изложеното до тук става ясно, че системното изграждане и развиване на професионалната квалификация и необходимия комплекс от умения за работа в туристическата индустрия се възприема от съответните браншови и световни организации (както в ЕС, така и в глобален мащаб), като задължително условие за осигуряване на устойчиво развитие на работната сила, наемана в туризма.

Ясно е, че от една страна, туристическите организации са тези, които са отговорни за обучението и развитието на наличните си човешки ресурси, за да са в състояние да постигнат поставените си бизнес-цели. От друга страна, самите работници също носят отговорност да се стремят и да бъдат мотивирани да развиват собствените си професионални знания и умения чрез системното им надграждане, за да бъдат достатъчно конкурентоспособни на трудовия пазар. В тази връзка възникват редица въпроси: до къде свършва ангажираността на образователните институции за професионалното формиране на младите кадри и от къде нататьк започва ангажираността на организациите и на самите работници за развиване и надграждане на придобитите вече професионални знания, умения и квалификация? Каква е ролята на висшето образование по туризъм за изграждането на професионалисти за туристическата практика, способни да отговорят адекватно на високите изисквания към туристическите продукти и услуги на клиентите?

Настоящата публикация представя част от изследване, свързано с опита да се отговори поне на част от тези въпроси, чрез изпълнение на целите на научен проект на тема: Предпоставки за професионална реализаџия на студентите от специалност „, Туризъм” при ИУ-Варна на територията на туристически район Варна (Северно Черноморие) $u$ туристически район Бургас (Южно Черноморие), по научен приоритет „Регионална политика и икономика”, по професионално направление 3.9 ,ТУРИЗЪМ”.

Предмет на тази статия е практическото обучение на студентите по туризъм, а целта e да се обърне внимание на проблемите и възможностите за интегриране на младите високообразовани професионалисти в сферата на туристическата индустрия на основата на практическото им обучение и да предложи методология за изследване на ефективността му. Изследователските задачи се свеждат до: първо да се синтезират най-често срещаните проблеми, особености и тенденции при организацията, провеждането и отчитането на резултатите от практическото обучение на студентите по туризъм в различни страни. Второ, на основата на анализа на съществуващите организация на провеждане и инструменти за измерване на ефективността на практическото обучение на студентите от специалност „Туризъм“ при Икономически университет - Варна, да се предложи конкретна методология за изследване. 
Авторите се надяват с тази публикация да допринесат за повишаване ефективността на практическото обучение на студентите по туризъм в Икономически университет - Варна, както и да подпомогнат усъвършенстването на студентското практическо обучение по туризъм в България така, че то да носи ползи на всички заинтересовани страни: студенти и бъдещи служители, клиенти, работодатели, регионален бизнес, трудов пазар, национална икономика.

\section{1. Студентското практическо обучение: изследване на проблема}

С цел открояване на повтарящи се проблеми, особености и тенденции в глобален аспект при организацията, провеждането и отчитането на студентското практическо обучение, ще се анализира състоянието му в дванадесет страни: Австралия, България, Великобритания, Египет, Индия, Кения, Малайзия, Румъния, Сингапур, Турция, Филипини, Хърватска.

Повечето програми за студентско практическо обучение в посочените страни изискват поне един семестър от контролиран опит на терен или стаж. Тези практики, свързани с работата в туризма, дават възможност на студента да работи в дадена туристическа организация, където му се възлагат задачи, пряко свързани с професионалната насоченост на обучението му и професионалния му интерес. Практическото обучение обикновено е на непълно работно време и покрива продължителността на академичния срок или семестьр. Съществуват и други видове студентско практическо обучение, които могат да бъдат на половин работен ден или на пълен работен ден. В някои организации изплащат стипендия, която да покрива пътните разходи и наема на жилището. Някои работодатели осигуряват скромен доход, но рядко предлагат медицински или пенсионни помощи. Както платените, така и неплатените стажове обаче, могат да предоставят отлични възможности за придобиване на професионален опит, свързан с кариерата. Някои ключови ползи на студентското практическо обучение се състоят в това, че студентите придобиват опит чрез прилагане на придобитите знания и умения в ситуации, свързани с работата. Практикантът е стимулиран да научи какво може да прави и какво му е необходимо, да научи още за да може да бъде ефективен в работата си в практиката. Чрез практическото обучение практикантът може да придобие практическия опит, от който работодателите се нуждаят и обичат да виждат в резюмето на кандидата за работа. Също така може да помогне за разширяване на познанията на стажанта, като наблюдава как другите решават проблеми.

Някои основни ценности на практическото обучение включват придобиване на опит чрез прилагане на придобитите в академична среда знания и умения в ситуации, свързани с работата. Изясняването на кариерните цели на практиканта чрез студентското практическо обучение му помага да си изясни дали тази професия му харесва и дали би я избрал за поле, в което да развива кариерата си. По време на практическото обучение студентът също научава как да създаде мрежа от контакти, ментори и референции, които да му бъдат полезни за бъдещите препоръчителни писма и професионална подкрепа. Въпреки, че туристическите организации нямат задължение след приключване на практическото обучение да наемат студента като служител на пълен работен ден, има и такива случаи, когато това се случва. Практическото обучение на студентите много често се превръща в инструмент за предварително набиране, който позволява на работодателя да види колко добре даден човек се вписва в културата на компанията. Бившите практиканти представляват една потенциално добра група, която може да осигури набор от подходящи потенциални кандидати при разкриване на вакантни дльжности.

Анализът на публикациите, изследващи практическото обучение на студентите по туризъм в посочените страни, откроява някои характерни особености и тенденции при реализацията му, като по-важните от тях са следните:

Австралия: Проучването на Уанг (Wang, 2008) открива значителна разлика между 
възгледите на професионалистите в индустрията и университетите в Австралия. Забелязва се разлика първо, по отношение на относителната стойност на висшите степени за туристическите професионалисти; второ, относно относителното съдържание на уменията и способностите, необходими за работа в туристическия сектор; и трето, относно относителната стойност на различните дисциплини, преподавани в университета. Изследването установява различия между съществуващата учебната програма по туризъм на университетско ниво и нуждите на туристическата индустрия. Резултатите показват, че висшето образование в туризма не трябва да бъде изолирано от реалната практика и че тези, които участват в проектирането на учебните програми, трябва да работят тясно с представители на индустрията, за да се осигури силна връзка между теорията и практиката. По този начин ще се подобри вероятността завършилите висше образование в туризма да се дипломират с необходимия набор от знания и умения, тясно съобразени с нуждите и очакванията на туристическата индустрия.

България: Редица изследвания за България през последните години осветляват различни аспекти на студентското практическо обучение. Така например, Луканова (Луканова, 2008) изтъква съществуването на няколко проблема: първо, липсват механизми за осигуряване на връзка между академичната институция и туристическия бизнес относно организацията му - намирането на работа зависи от инициативността на студентите, както от персоналните контакти на преподавателите от университета/катедрата. Второ, липсва съществен контрол върху провеждането на практическото обучение и трето - съществува наличие на формализация на практическото обучение. Всичко това създава силно затруднение или дори невъзможност да се постигнат целта и задачите му. Илиева и Калудова (Илиева и Калудова, 2013) разглеждат възможностите за усъвършенстване на теоретичните познания и професионалните умения и изграждане на управленски опит у студентите чрез провеждането на комбинирани тематични занятия, като в същото време предлагат и насоки за избор на кариера в хотелиерството.

Великобритания: Бъсби и Гибсън (Busby and Gibson, 2010) изследват по какъв начин се изгражда връзката индустрия-университет-държава при провеждането на практическо обучение на студентите по туризъм от Великобритания зад граница, за срок от 12 месеца. Според авторите, стажовете не само осигуряват запознаване с професионалната практика, те повишават професионализма на завършилия студент на пазара на труда и, вероятно, повишават зрелостта на индивида, преди да той да се върне в последната степен на обучение - магистьр. Освен това се придобива и житейски опит, като комбинацията от тези два аспекта увеличават способността на студентите да влияят върху качеството на туристическия бизнес.

Ezunem: Изследването на студентските нагласи и възприятия спрямо практическото обучение е обект на анализ на публикацията на Мекауи и Бакр (Mekawy, Bakr, 2014). На основата на количествено проучване чрез въпросник от 47 въпроса, резултатите разкриват, че респондентите имат значително различни възприятия относно тяхната роля и значение при участието си във, и разработването на стажантски програми. Документът представя интересен концептуален и планиращ модел, наречен РPAF-цикъл, за постигане на ефективност при организирането и провеждането на програми за стаж, засилващи приноса на стажантите. Важно е, че този документ заключава, че успехът на планирането на стажантските студентски програми зависи от партньорството между представителите на организацията, университета и студентите. Трите страни трябва да постигнат съгласие относно компонентите на плана за практическо обучение, отговорностите на всяка страна и изискванията за отчитане. Подчертава се че ролята на университета е ключова за изграждането на ефективно взаимодействие.

Индия: Практическото обучение на студентите по туризъм е обект на изследване и на Дата и Джа (Datta and Jha, 2015), поради бързото разрастване на туристическата индустрия в Индия и нарастващата й нуждата от високо квалифицирани професионални кадри. В 
статията се прави опит да се идентифицират факторите, определящи избора на кариера в туризма и да изследва разликите в перцепцията на кариерата на две групи студенти: такива, които вече са преминали през практическото си обучение, и тези, които все още не са. Резултатите сочат, че при първата група са се формирали негативни нагласи спрямо работата в туризма, докато при втората група те все още липсват. Причините за негативните нагласи, според авторите, са няколко: прекалено големите предварителни очаквания на студентите, разминаващи се с действителността и поради това - генериращи високи нива на стрес и напрежение; лошите условия на труд, поради факта, че студентите намират работа в ниско категорийни хотели и ресторанти; не дотам доброто отношение на някои мениджъри към тях. Като цяло, студентите смятат, че индустрията не им предлага работата, която рекламира и която те очакват да работят за цял живот. Това води до демотивация и отлив на професионално обучени кадри, а от там - спадане качеството на обслужване и на туристическия продукт.

Кения: Камунзю (Kamunzyu, 2010) насочва вниманието си към предизвикателствата, пред които е изправена връзката между туристическата индустрия и висшето образование по туризъм. Проучването има за цел да определи дали теорията и практиката в учебната програма по хотелиерство са обвързани.Друга цел на изследването е да се установи ролята на преките ръководители на работното място за изграждането на добри взаимоотношения между университетското образование и туристическата практика. Изводите от изследването открояват няколко основни проблема: липса на адекватно обучение, подкрепа и управленско ръководство на студентите по време на практическото им обучение в практиката; липса на подходящи средства и време, отпуснати за посещения в туристическата индустрия, и обърнат приоритет на ролите, които играят непосредствените ръководители на работата на студентите по време на тяхното практическо обучение.

Малайзия: Абдулах и колектив (Abdullah, et al., 2015) фокусират изследването си върху евентуалното разминаване между академичното образование по туризъм и реалността в туристическата индустрия. Резултатите показват, че учебните програми не се актуализират редовно и това води до придобиване в университета на остарели вече знания. Голяма част от университетите, обучаващи студенти по туризъм в Малайзия не създават перспективност на работата в туризма, защото не подпомагат по никакъв начин професионалната реализация и набиране на опит на студентите си при реализацията на тяхното практическо обучение. Изказва се мнението, че спешно е необходимо да се установи, възможно най-скоро, тясно сътрудничество между университетите и туристическата индустрия, с оглед по-ефективното им коопериране.

Румъния: Балтеску (Baltesku, 2016) анализира нагласите на студенти от четвърти курс и студенти-магистри от специалност „Туризъм, тьрговия и услуги“ във Факултета по икономически науки и бизнес администрация - Брашов, относно съдържанието и организацията на практическото обучение, като извежда някои основни проблеми: има компании, които не се интересуват от организирането на тази дейност и стажантската програма става безполезна или персоналът оценява, че присъствието на студенти е бреме. Има дори ситуации, когато студентите се възприемат за безплатна работна сила, лесно подлежаща на експлоатация. Тези аспекти очертават недостатъците на стажантските програми, но също така и насоките за подобряване, като: увеличаване на ефективния брой часове за практическо обучение, адаптиране на теоретичното съдържание към конкретни икономически дейности, подобряване на учебната програма на стажантската дисциплина, а също и подобряване на управлението на цялостното практическо обучение.

Сингаnyp: Чен (Chen, 2016 ) насочва изследването си върху три практики за развитие, които насьрчават успеха на програмите за практическо обучение в Сингапур: предоставяне на студентски стажове в Сингапур в чужбина, за насьрчаване на добрата междукултурна адаптация и компетентност; намаляване на проблемите на работното място, пред които са 
изправени студентските стажове в чужбина и в Сингапур; разработване на възможности за студентски стаж в чужбина и в Сингапур, които да обогатят практическите преживявания, полезни за студентите в бъдеще. Проучването заключава, че дизайнерските курсове спомагат за по-тясната специализация и имат практически ориентирани характеристики. Тези курсове улесняват стажовете на студентите в Сингапур и в чужбина, което позволява на стажантите да се адаптират по-лесно към културните различия в работата и живота в Сингапур, активни през целия стаж.

Туричи: Кашлъ и Илбан (Kasli and Ilban, 2013) изследват взаимовръзката между възникналите проблеми по време на студентското практическо обучение в туристическата индустрия и последващото ниво на (не)желание за работа в туризма. Резултатите от проучването показват, че проблемите, с които студентите се сблъскват по време на стажовете, имат отражение както за университетите, така и за бизнеса. Съвременната практика на стаж изисква преразглеждане на учебните програми и изобщо - организацията и провеждането им от университетите. Освен това, резултатите сочат, че бизнес секторът не предоставя необходимото внимание, компенсации и професионални условия за студентитестажанти. Това обаче, представлява сериозна бариера за повишаването на качеството на услугите, тъй като повечето обучаващи се, които работят при лоши условия, предпочитат други отрасли пред туристическата индустрия след завършването. За да смекчат тази загуба, предприятията трябва да подобрят условията на труд на своите стажанти.

Филипини: Михм, (Mihm, 2016) насочва вниманието си към измерване нивото на удовлетвореност у студентите от практическото им обучение, организирано и проведено от Палестра Консорцио. Изследването илюстрира нагледно добрите практики в сектора, като показва изключително високи нива на удовлетвореност, особено що се отнася до провеждането на предварителното обучение и ориентация, предоставяни преди всяко назначение на студенти в туристическата индустрия. В заключение се обобщава, че професионалните услуги, предоставени от Палестра Консорцио подпомагат студентското практическо обучение, като оказват внимание и подкрепа на студентите от началото до края на обучението им. Отчита се и положителното влияние на практическото обучение на студентите върху качеството на туристическите услуги и туристическия продукт във Филипините.

Хърватска: Перман и Микинач (Perman and Mikinac, 2014) имат един по-различен поглед върху практическото обучение - те правят опит да намерят обяснение на проблема с образованието и обучението на персонала в сектора на хотелиерството и туризма, който заема специално място и специално внимание сред работните места в туризма и хотелиерството. Общото качество в сектора на хотелиерството и туризма зависи именно от образованието и обучението, т.е. от общото ниво на образование на заетите служители. От тази гледна точка се засяга и качеството на студентското практическо обучение. Образованието на персонала и тяхното професионално развитие се извежда като найважният фактор, който пряко и косвено се отразява на конкурентоспособността на туристически продукт. Според авторите, предварителното въвеждане в работата в туристическата индустрия чрез студентското практическо обучение се явява важно звено в целия етап на професионална подготовка.

В следствие на анализираните практики в различните страни могат да се изведат следните обобщени проблеми, особености и тенденции, свързани с провеждането на студентското практическо обучение:

- Проблемите със студентското практическо обучение влияят на намерението за работа в туристическия бизнес, поради честото формиране на негативни нагласи у студентите спрямо бъдещата им професия;

- Особеностите и проблемите, свързани със студентското практическо обучение най-често се проявяват в следните случаи: А) проблеми с работното място; Б) 
нарушено работно време и почивки и задаване на допълнителни часове, без това да се заплаща; В) неупражняване на необходимия надзор и контрол; Г) липса на, или недостатъчно въвеждане в работата и непознаване важността на работата; Д) проблеми със заплащането; Е) липсата на обучение, неглижиране работата на студентите от страна на мениджърите; Ж) понякога студентите стават обект на тъмно лидерство и биват директно дискриминирани или лишавани от пълноправни права на труд и справедливо възнаграждение; 3) разминаване между твърде високите очаквания от работата и действителността; И) не винаги съдържанието на учебните програми отговаря на нуждите на туристическата практика.

2. Методология за изследване на провеждането на практическо обучение на студентите от специалност „Туризъм” при Икономически университет-Варна.

Поддържането на постоянна връзка с туристическите организации при провеждане на практическото обучение на студентите ОКС „бакалавър” в специалност „Туризъм” е неизменна част от визията на катедра „Икономика и организация на туризма” при Икономически Университет-Варна за предлагане на високо качество на образованието по туризъм. Целта е, осъществяване на дългосрочно сътрудничество и партньорство между университетското обучение и туристическата практика в България. Затова и анализът на настоящото изследване се свързва с разбирането, че академичното обучение по туризъм и практическото обучение, трябва да са взаимообвързани и да кореспондират с актуалните тенденции и практики в туристическата индустрия.

Към настоящия момент, практическото обучение в катедра „Икономика и организация на туризма" се осъществява под различни форми, като една от тях е провеждането и защитата на задължителен професионален производствен стаж, съгласно учебния план след трети курс. Програмата е част от обучението на студентите от специалност „Туризъм” в Икономически университет - Варна. Целта е да се задълбочат практическите знания на студентите чрез проучване на дейността на туристическите предприятия, анализ на конкретни проблеми с лични изводи и препоръки.

Задължителният стаж е 45 календарни дни или 240 часа и може да се осъществи в рамките на една календарна година, от месец септември на настоящата учебна година - до месец септември на следващата учебна година. Студентите сами намират фирма, в която да го провеждат. Катедра "ИОТ" признава и проведено практическо обучение по проекта на МOH "Студентски практики", както и учебно тренировъчните практики (студентски бригади) по специалността.

От учебната 2017/2018 година, отчитането на практическото обучение се осъществява единствено през университетската платформа за сьтрудничество с бизнеса UEBN (http://uebn.ue-varna.bg/bg/). След направена регистрация, студентите избират една от функционалните възможности на платформата за защита на практическото обучение, а именно:

- (тип 1) Студенти на стаж 240 часа, разпределени в минимум 45 дни,

- (тип 2) Студенти, работещи на основен трудов договор,

- (тип 3) Студенти, развиващи собствен бизнес.

Методология на изследването: Настоящото проучване се осъществява във връзка с изпълнението на научен проект на тема: Предпоставки за професионална реализация на студентите от специалност „Туризъм” при ИУ-Варна на територията на туристически район Варна (Северно Черноморие) и туристически район Бургас (Южно Черноморие), по научен приоритет „Регионална политика и икономика”, по професионално направление 3.9 „ТУРИЗЪМ”.

Темата на научния проект е непосредствено свързана с проблемите на регионалното развитие и интегрирането на младите високообразовани професионалисти в сферата на 
туристическата индустрия. Предмет на изследването е практическото обучение на студентите от специалност Туризъм при ИУ-Варна. Цел на изследването в проекта $е$ да се разкрие ролята на практическото обучение за изследване на взаимовръзката между заинтересоваността на бизнеса от квалифицирани кадри за неговата дейност и сезонността, като подсилващчи фактори на проблема $c$ текучеството, проблеми $c$ количеството и качеството на кадрите, регионалната реализация на кадрите $u$ задържането им на регионален приниип.

Пьрвата изследователска задача, свързана с целта, е систематизиране на теорията и практиката в областта на професионалната реализация на кадрите в туризма и разработване на тази основа на:

- Методология за изследване на провеждането на практическото обучение на студентите от специалност Туризъм при ИУ-Варна;

- Методика, в т.ч. анкетни карти за проучване, анализ и оценка на състоянието на практическото обучение на студентите от специалност Туризъм при ИУ-Варна, структурирани и полу-структурирани интервюта.

Втората изследователска задача е провеждането на проучване на заинтересованите страни по отношение на проблемите, съпътстващи практическото обучение, реализацията и развитието на кадрите в туризма. И по-конкретно осъществяване на проучване сред:

- Местни управленски структури на регионално ниво - с цел установяване на текущото състояние на действащите стратегии, планове и програми, насочени към развитието на туризма и обезпечаването на професионално подготвени кадри за него.

- Мениджъри на туристически обекти - посочващи характерните проблеми при наемането и управлението на практиканти

- Студентите от ИУ-Варна, специалност Туризъм, установяващо проблемите при подготовката и реализацията на практическото обучение, отразяващи заинтересоваността и помощта от страна на бизнеса за интегриране на практикантите в работната среда.

- Икономически Университет-Варна, като образователна структура, свързваща студентите с техните бъдещи работодатели.

Проучването ще се извърши на базата на проведени анкети сред студентите от специалност „Туризъм“ и представители на туристическия бизнес в двата изследвани района, както и разговори с представители на регионалните туристически бизнес структури и изследване функционирането на новосъздадената платформа UEBN в ИУ-Варна. ${ }^{1}$

Основните функиии на анализа и оценката на провеждането на професионално практическото обучение в специалност „Туризъм” са:

- дескриптивна: измерване и описване на важни за вземането на управленски решения по отношение на професионално практическото обучение в специалност „Туризъм”показатели;

- диагностична: дефиниране на проблемите свързани с професионално практическото обучение в специалност „Туризъм” и техните причинители на основата на сравнителен и конкурентен анализ;

- прогнозна: предвиждане на алтернативни сценарии за развитие на професионално практическото обучение в специалност „Туризъм” в резултат на влиянието на микро- и макросредата;

- пре-скриптивна: препорьчителни действия и насоки за развитие с отчитане на комплексните въздействия на различните фактори и специфичните условия, в които се реализира професионално практическото обучение в специалност „Туризъм”, (промяна на учебна

${ }^{1}$ https://uebn.ue-varna.bg/bg/subpage/120, 18.10.2019 
документация, демография, глобализация, дигитализация, нови технологии и др.),

- мониторингова: проследяване поведението на студенти, бизнеса и регионалните управленски структури и оценяване ефективността на препоръчаните мерки.

Анализът и оценката на провеждането на производствения стаж в катедра "ИОТ" при Икономически Университет- Варна ще бъдат свързани със специфичен изследователски процес, поради следните обстоятелства:

- Необходимост от полево проучване, тъй като няма официални оперативни и статистически данни, нито вторични източници на информация.

- Особеностите на респондентите-студенти, за които се знае твърде малко като участници в проучването. Същевременно те ще могат да бъдат включени в оценката на провеждането на производствения стаж в катедра "ИОТ" при Икономически УниверситетВарна само по време на обучението си след трети курс.

- Комплексност на изследвания обект- студентите, както и експертите имат сложно и разнообразно поведение, което е резултат от разнопосочните им потребности, преценки, мотиви при осъществяване на професионално практическото обучение.

- Трудности и пречки от организационен и технически характер за определяне на поведението на студенти и експерти спрямо предлаганите от Икономически университет условия и правила за провеждане на професионално практическото обучение по специалността.

- Ограничения, дължащи се на спецификата на обучението по „Туризъм” в Икономически Университет-Варна.

Предвид посочените особености, ще се проведе полево проучване, което да осигури информация за отношението на студенти, мениджъри на туристически обекти, местни структури и университет към провеждането на професионално практическото обучение в специалност „Туризъм” при ИУ-Варна. За да се осигури по-висока степен на пълнота на информацията, в проучването ще бъдат включени и експерти от бизнеса, мениджъри на туристически обекти, представители на местни управленски структури. Поради различието на двете генерални съвкупности в изследването (на студентите и на бизнеса) ще се проведат две отделни анкетни проучвания.

Предварително ще се разработят две отделни анкетни карти (за бизнеса и за студентите от специалност „Туризъм”, завършили трети курс), както и информационен лист за обратна връзка, който ще се попълва само от студентите. Анкетата (иисмено допитване) е дескриптивен метод за събиране на данни с помощта на предварително разработен въпросник, съдържащ въпроси за поведението, намеренията, нагласите и демографията на респондентите. В сравнение с други методи на допитване за него са характерни следните по-важни особености:

$\checkmark$ като цяло контрольт върху средата е нисък;

$\checkmark$ чрез него може да се събере средно голямо количество данни;

$\checkmark$ степента на възприемана поверителност (анонимност) е най-висока;

$\checkmark$ сравнително бързо може да се осъществи;

$\checkmark$ има средно високо равнище на отговаряне.

Въпросникът за студентите,

Анкета 1 ще се разпространява сред студенти от спец. „Туризъм”, завършили трети курс през изминалите три учебни години $(2017 / 2018,2018 / 2019,2019 / 2020)$ и ще съдържа 15 въпроса.

Информационният лист за обратна връзка ще се разпространяван сред студентите от спец. „Туризъм”, завършили трети курс през изминалите три учебни години (2017/2018, 2018/2019, 2019/2020) и ще съдържа 18 въпроса.

Въпросникът за експертите- мениджърите на туристически обекти - Анкета 2, ще се разпространява онлайн сред мениджърите на туристически обекти, потребители на кадри от специалност „Туризъм” при провеждане на професионално практическо обучение. 
Периодът на анкетиране на бизнеса ще обхваща месеците юни-октомври за изминалите три календарни години $(2017,2018,2019)$ и ще съдържа 15 въпроса.

За открояване на събраните данни по-нататьк ще се използва количествен $u$ качествен анализ.Това обстоятелство налага да бъдат направени следните уточнения:

Извадката от пьрвата генерална сьвкупност ще отразява мнението и оценките на студенти от спец. „Туризъм”, завършили трети курс. Около 80\% от анкетите за студенти ще се проведат в Икономически Университет-Варна при защитата на практическото обучение на редовна или поправителна сесия, а $20 \%$ от тях ще се разпространят чрез електронната платформа за сътрудничество с бизнеса UEBN.

Извадката от втората генерална съвкупност ще отразява мнението и оценките на мениджърите на туристически обекти, потребители на практиканти от специалност „Туризъм”. Тяхното участие в проучването ще бъде от голямо значение, поради факта, че те ще осъществяват непрекъснати „контакти със студентите” и ще познават изключително добре техните нагласи, потребности и желания.

Анкета 1, Анкета 2 и информационният лист ще са разпространявани само на български език.

Качеството на анализа на резултатите от всяко допитване ще зависи до голяма степен от естеството и характера на формулираните критерии и признаци за изследването на използваните в настоящото проучване въпроси. Основните им свойства са:

- точност - поставените въпроси целят получаване на информация за отношението на студентите и мениджърите към провеждането на практическото обучение за специалност „Туризъм” в ИУ-Варна;

- синтезираност - кратките въпроси предполагат по-бързи и точни отговори, следователно лесна и бърза обработка на получените резултати;

- яснота - съдържанието и тълкуването на поставените въпроси да са идентични за всички респонденти.

Въпросниците, използвани в проучването ще се състоят от следните отделно обособени части:

Анкетата за самооценка на студента ще се състои от две части: А) Практически умения; Б) Соџиални и личностни умения. Измерването се определя да бъде по скала от 0 до 6.

Информационният лист за обратна връзка ще се състои от три части: Въведение, Основна част и Заключение. Въведението ще е изградено от класификационни въпроси, отнасящи се до различни характеристики на респондента - курс, група, заемана длъжност по време на практиката, организация и др. Въз основа на тези въпроси при анализа респондентите ще бъдат групирани в хомогенни категории. Основната част ще включва въпроси, отнасящи се до практическото изпълнение на стажа, а именно: трудови отношения между страните, проведени обучения, адаптация и интеграция на практиканта в организацията, работно облекло, ниво на стрес и др. В Заключителната част на информационния лист ще се изисква от респондентите да бъдат изведени конкретни предложения и препоръки за обогатяване на програмата за провеждане на практическо обучение към катедра „ИОТ”, ИУ-Варна.

Онлайн анкетата за мениджьрите на туристически обекти ще цели набиране на първична информация за изследване на проблемите при наемането и управлението на практиканти от специалност "Туризъм" при Икономически Университет-Варна.

За събиране на емпирични данни в последната фаза на изследването ще са разпространени анкети от първи и втори вид и информационните листи. За попълване на голяма част от въпросниците ще са осъществени и лични срещи със заинтересованите по проблематиката страни.

За проучване на провеждането на практическото обучение в специалност „Туризъм”, ИУВарна ще се използва извадков подход за изучаване на сьвкупности. Измерването и оценките на параметрите на съвкупностите ще е опосредствано поради факта, че ще се изучават само 
ограничен брой представители на съвкупността.Целесъобразността на извадковия подход ще се свързва с неговата бързина, относително ниските разходи, по-малък размер на грешките в сравнение с изчерпателните проучвания. Модельт на извадката ще е от типа нецелева случайна извадка, която намира широко приложение при изучаване удовлетвореността на потребителите (студентите от една страна и бизнеса от друга).

\section{Заключение}

В настоящата публикация се представи част от изследване, свързано с изпълнение на научен проект на тема: Предпоставки за професионална реализация на студентите от специалност „,Туризъм” при ИУ-Варна на територията на туристически район Варна (Северно Черноморие) и туристически район Бургас (Южно Черноморие), по научен приоритет „Регионална политика и икономика”, по професионално направление 3.9 „,ТУРИЗЪМ”. Изследването цели да обърне внимание на възможностите за интегриране на младите високообразовани професионалисти в сферата на туристическата индустрия на основата на практическото им обучение и да предложи методология за изследване на ефективността му. В тази връзка, пьрво се синтезираха най-често срещаните проблеми, особености и тенденции, свързани с организацията, провеждането и отчитането на резултатите от практическото обучение на студентите по туризъм в различни страни. Второ, на основата на анализа на съществуващата организация на провеждане и инструменти за измерване на ефективността на практическото обучение на студентите от специалност „Туризъм“ при Икономически университет - Варна, се предложи конкретна методология за изследване и оценка на ефективността му.

\section{References}

1. Abdullah, R. et al. (2015) Hospitality Internships: An Employment Advantage or Perilous Experience. Journal of Basic and Scientific Research, 5(8), pp. 34-38. [Online] Available at: https://www.researchgate.net/publication/280722933_Hospitality_Internships_An_Employment _Advantage_or_Perilous_Experience [Accessed 01.10.2019].

2. Baltesku, C. (2016) The assessment of internship programs. A view point of the undergraduate tourism students from the Transylvania University of Brasov. Bulletin of the Transylvania University of Brasov, Series V, Economic Sciences, Vol. 9 (58), No.1, pp. 65-72. [Online] Available at: https://www.semanticscholar.org/paper/The-assessment-of-internship-programs-.A-view-of-\%C5\%9F-Adina-LTESCU/ac20c0ba3b897625d628abf29d92bde37bc8e849 [Accessed 05.10.2019].

3. Busby, G. and Gibson, P. (2010) Tourism and hospitality internship overseas: A British perspective. Journal of Hospitality, Leasure, Sport and Tourism Education, Vol. 9, No.1, pp. 412. [Online] Available at: http://citeseerx.ist.psu.edu/viewdoc/download?doi=10.1.1.608.2635\&rep=rep1\&type=pdf [Accessed 10.09.2019]

4. Datta, A. and Jha, B. (2015) Industrial Training and Its Consequences on the Career Perception - a Study in Context of the Hotel Management Students' at Jaipur. EPRA International Journal of Economic and Business Review, February, Vol.3, Issue 2, pp. 146-152. [Online] Available at: https://eprawisdom.com/jpanel/upload/articles/455pm23.Amit\%20Datta\%20\&\%20Dr.\%20Babit a\%20Jha.pdf [Accessed 30.09.2019]

5. Ilieva, K. and Kaludova D. (2013) The Catering Events at The College of Tourism in Burgas an Opportunity for Effectiveness' Enhancement of The Practical Education of The Students. Management and Education, Vol. IX (2), pp. 183-189. [Online] Available from: http://www.conference-burgas.com/maevolumes/vo19/bOOK\%202/b2_25.pdf [Accessed 10.09.2019]

6. ILO, (2010) Global Employment Trends for Youth. [Online] Available at: https://www.ilo.org/empelm/pubs/WCMS_143349/lang--en/index.htm [Accessed 05.09.2019]. 
7. ILO, (2019) World Employment and Social Outlook. [Online] Available at: https://www.ilo.org/global/research/global-reports/weso/2019/lang--en/index.htm [Accessed 05.09.2019].

8. Kamunzyu, E. (2010) Challenges Facing Hospitality Industrial Attachment as a Learning Experience in Selected Institutions in Nairobi - Kenya. Master Thesis, Department of Hospitality Management, Kenyatta University. [Online] Available at: https://pdfs.semanticscholar.org/c271/0fcc3b1cf41592850d93931f6eaf7f4c6388.pdf [Accessed 11.09.2019]

9. Kasli, M. and Ilban, M. (2013) The Influence of Problems Faced During Internships on Interns' Views of Their Profession and Their Intention to Work in the Tourism Industry. Eurasian Journal of Educational Research, Issue 52, Summer, pp. 79-96. [Online] Available at: https://files.eric.ed.gov/fulltext/EJ1060369.pdf [Accessed 10.10.2019]

10. Lukanova, G. (2008) Organization of the Vocational-Practical Training of the Students in The Tourism Major At The University of Economics - Varna. Economics and Management, Faculty of Economics, SOUTH-WEST UNIVERSITY “NEOFIT RILSKI”, Blagoevgrad, Vol. 4(3), pp. 66-70. [Online] Available from: https://ideas.repec.org/a/neo/journl/v4y2008i3p66-70.html [Accessed 10/09/2019]

11. Mekawy, M. and Bakr, M. (2014) Planning Internship Programs: Tourism Students' Perceptions. Tourism, Vol.62, No.1, pp. 41-61. [Online] Available at: https://hrcak.srce.hr/120558 [Accessed 10.09.2019]

12. Perman, L. and Mikinac, K. (2014) Effectiveness of Educational Processes in Tourism and Hospitality in the Republic of Croatia. Tourism and Hospitality Industry, Congress Proceedings: Trends in Tourism and Hospitality Industry, pp. 616-630. [Online] Available at: https://ideas.repec.org/p/tho/iscthi/confpap05.html [Accessed 10.10.2019].

13. Tuzon, T. (2016) Tourism and Hospitality Students' Level of Satisfaction of Their Internship Experience. LPU-Laguna Journal of International Tourism and Hospitality Management, Vol.3, No.2, September, pp. 83-99. [Online] Available at: http://lpulaguna.edu.ph/wpcontent/uploads/2017/07/TOURISM-AND-HOSPITALITY-STUDENTS-LEVEL-OFSATISFACTION-ON-THEIR-INTERNSHIP-EXPERIENCE.pdf [Accessed 10.10.2019].

14. University of Economics-Varna Business Network, [Online] Available from: https://uebn.uevarna.bg/bg/subpage/120 [Accessed 19/10/2019].

15. Wang, J. (2008) Is tourism education meeting the needs of the tourism industry? : an Australian case study. Master Thesis, University of Canbera, Faculty of Business and Government. [Online] Available from: http://www.canberra.edu.au/researchrepository/items/1d7eef38-6d47552b-673e-adb17f0c721a/1/ [Accessed 07/09/2019]

16. Yen-yen, Ch. (2016) Successful Training Classes for Overseas Internships - Singapore Overseas Internships Success Stories at Tajen University. International Journal of Business and Commerce, Vol.4, No.5, pp. 01-19. [Online] Available at: https://www.ijbcnet.com/4-5/IJBC15-4501.pdf [Accessed 07.09.2019]. 